\title{
IMPROVING THE STUDENTS READING COMPREHENSION THROUGH MIX FREEZE GROUP STRATEGY
}

\author{
Meningkatkan Membaca Pemahaman Siswa Melalui Strategi Mix Freeze \\ Group
}

\author{
Muhammad Astrianto S \\ English Education Department, Faculty of Teacher Training and Education \\ Muhammadiyah University of Makassar
}

\begin{abstract}
This research aimed to explain the improvement of the students' reading comprehension in terms of Specific Information of the text dealing with main ideas and sequence of details and Creative Reading of the text dealing with characterization and conclusion. To explain the improvement, the researcher used a classroom action research (CAR) which was conducted in two cycles in which every cycle consisted of four meetings. The location of this research was taken at the second grade students of SMAN 1 Bontomarannu with a number of the subject were 35 students. The research findings indicated that the application of SMAN 1 Bontomarannu) Strategy was significant in improving the students' reading comprehension in terms of Specific Information and Creative reading of the text. It was proved by the mean score of cycle I was 60.69. It was classified as fair then improved to be 73.38. It was classified as good in cycle II. They are higher than the mean score of diagnostic test namely 50.7 that classified as poor. Therefore there was the improvement of the students' reading comprehension in terms of Specific Information of the text dealing with main ideas and sequence of details and Creative Reading of the text dealing with characterization and conclusion.
\end{abstract}

Key words: reading comprehension, mix freeze group

Today, there a lot of information, people should know, and they should find many kinds of information sources that are written in English. Thus to get information, people should read many kinds of information. Reading is a source of getting information. No one can get much information without reading. Actually, Reading is the easiest and the cheapest way to get information, because it can help to know the simple information to the more complex one. In addition, the main important thing that the readers should have the ability to comprehend what they have read.

As long some approaches had been applied to improve the students' reading comprehension at the school, but those approaches still weak, in the other words those approaches are not significant to improve the students' achievement in reading comprehension, the students still can not get the ideas and unseriously to read more. The desire to read, as well as the capability to read, must be present for 
the successful recognition and analysis of text, especially the compleks reading text of language.

From the problems above the researcher will apply one of teaching strategy. This is an interesting strategy and it can increase the student's reading ability namely Mix Freeze Group Strategy to improve the students' reading comprehension. This strategy is designed to create the students' target score is 70.

Pressley and Block (2002) also suggested that teachers can learn and teach by using strategy, how the strategies work and become better able to teach them to their own students by applying the strategies to their own reading. Based on Kagan that one of strategy that can be used in teaching reading is a "Mix Freeze Group" method, which is interesting and enjoyable for the students.

Therefore to overcome this problem the researchers applies a concept or strategy Mix Freeze Group. This learning strategy is expected to solve the problems faced by the students and the students will better understand the content of reading they will learn. Students will be more motivated by the strategy is applied by teachers. This strategy can also guide students in learning to read because it directly supervised during the learning process. Beside that the effectiveness of the Mix Freeze group strategy of Reading Training can improve the students' auditory processing (understanding) and classroom behavior (Madaule, 1993).

\section{Concept Of Mix, Freeze Group Strategy}

Kagan (1994) Developed Cooperative learning is called Mix Freeze Group Strategy to improve a class building and a type of structural peer interaction emphasizing positive human relationship in the classroom and uses to stimulation to train and develop reading related communication, language, and learning skill group. The idea is the strategy is designed to replicate, through thingking, interpreting the various steps of the student's development with respect to reading, vocabulary and language. The strategy, structures, and procedures of the Mix, Freeze Group Strategy can develope students' interaction and mastering vocabulary. Mix Freeze Group Strategy is a class building and content mastery 
strategy developed, this strategy can be used in many skill not only reading but also listening and speaking.

Kagan (1994) states that though often confused with group work, Mix Freeze Group is actually a specific structure of educational skill that emphasizes individual accountablity and classroom synergy. several structures-or team work to improve students'content mastery. some structures can be used for basic class building too.

Barbara, and Kathy (1995), argues that Mix Freeze Group Strategy is classroom activities which the structures stress positive interpersonal peer relationship, equality, self esteem, and achievement. Students can work together by following the step to the structure, using material or content selected by the students them self or by the teacher. Basicly this strategy has structural appcoach to cooperative learning and make the students are interested the class building teaching learning process.

Kagan has developed Mix Freeze Group“ structures” which may be thought of as steps to classroom activities with structural approach various aims, such us:

a. Building team spirit and positive relationships among students

b. Information sharing

c. Critical thinking

d. Communication skill

e. And mastery (learning/remembering) of specified material

Many of the stuctures can fulfil a number of aims simultaneously, depending on how the teacher uses them. Mix Freeze Group Strategy is good too for review of match facts variation in how the questions are asked keep the game interesting. The students discussing how to keep all engaged in that learning.

\section{The History Of Mix Freeze Group Strategy}

Mix Freeze Group Strategy is one the types of cooperative learning strategy, it was proposed by Kagan at California University in 1994 which is the most edition to his teory and has been met with more resistance than others type 
of cooperative learning, it also has been implemented in Japan by Jane JoritzNakagawa (Aichi University of Education) in 1998. ( Kagan, $1994: 12$ )

This strategy briefly describes and discusses Spencer kagan's approach to cooperative learning Mix Freeze Group. Mix Freeze Group Strategy in cooperative learning is a type of structured peer interaction emphaizing positive human relationships, colaboration between peers, active learning, academic achivement, equal participant, and equal status of students in the classroom. it can be used to teach any subject matter, whether that be foreign languages, math, social studies, etc.

Kagan approach structures that provide communication activities in the classroom, where students can collaborate with each other in supportive, sharing and egalitarian ways, with content provided by the teacher or students. (Jalt Association: 1994)

\section{Characteristic Of Mix, Freeze Group Strategy}

According to Laure Candler 1998, The Characteristic of Mix Freeze Group are:

a. Finding more vocabulary

Mix Freeze Group Strategy can apply in many subject materials such as reading text, listening and speaking group, in content mastery it sould be guided and know more vocabulary, specifically in reading text the students read and understand the words means and interprate the text content. This strategy guided us to read more vocabulary and share with the partner to solve the problem given. b. Have keen many sensory (sigh,sound, brain, tought, ) to notice and reach the word means.

This strategy involved our sigh, our mind, and our though to respons the material. We have to speak with our partner, share with our group and read and think the text carefully by using our own sigh and tought. To reach the materials aims the students must have sensory in other that the problem being solved.

c. Interested in reading text, Story and Dialoque

This strategy can apply in reading, speaking and listening. This strategy like enjoy to read and understanding or listen what we talk about. The students will 
enjoy read the text, story or listen the dialogue because they are in freeze and they can share their ideas and thinking.

d. Expresses students's self and tinking

Because this strategy involved the students' mind and their power so they must be active in learning process, the results of the activity the students expreses their self to through the structure and also expresse their thinking what they have read and tell their team groups.

e. Involved interaction and communication

Absolutely this strategy involved interaction to materials, students and other groups. They dont do it by it self but they need comunicate the problem to their group to share their ideas and tinking, they also need discussion each other what have they read of the text to answer the question given.

\section{The Principle Of Mix Freeze Group Strategy}

a. Greater Comprehensible input. student adjust their speech to the level of their partner because they are working together.

b. Negotiation meaning. Student have the opportunity to adjust their language output to make sure they understand each other.

c. Lowered Affective filter. Whereas it is frightening to speak out infront of the whole class, it is easy for student to read, talk and to write with a supportive teammate.

d. Peer Support. Student encourage and support each other in tem work language use.

e. Enhanced Motivation. Because the structures are engaging interaction sequences, and students need to understand each other there is high motivation to speak, write and reading for understanding.

f. Greater language Use. Using a pair structure such as Time pair share, it takes but two minutes to give every student in the class a full minute of language output opportunity.

Whole-class question answer, to provide the same amount of reading and written language. each student would take over an hour because the teacher is giving question on the paper. and responding to each student at time. these 
principle of the Kagan structures are documented and detailed at length in two publication: (Kagan, 1994. Kagan \& Mc Groarty, 1995.)

\section{The Structural Approach To Mix Freeze Group Strategy}

a. Grouping of Students:

1) The researcher grouping the students by saying Mix for the first time and the students will walk around the classroom to find partner be a group.

2) The students will have time to read and share their ideas to answer the question on the reading text.

3) The researcher grouping again the students by saying Mix to find more members into their group, than freeze them again in giving them time to read and share their ideas each other and answer the next question. It will be continue until the group has been formed be four or five group.

4) The students are given time again by the researcher to share again about what have they read and make conclusion, then collect their task and then telling what have the student read infront of the class.

b. Materials Needed:

1) Materials necessary for reading skill, story text or dialuge teks.

2) Researcher should have questions prepared that can be answered on a paper.

c. Direction:

1) Student will walk arround the room in all direction and areas.

2) Student will get lost or found

3) Researcher will yell 'Freeze'"

4) While students are frozen, the researcher gives time to the students for read and share each others to answer the question .

The researcher can make group of students in the classroom. for the first the researcher yells mix and than directly the student walk around in the classroom to find the closest partner be two members in a group, and when the researcher yells freeze the student must be stop and read the text carefully while share the idea and answer the question. Next the researcher yells mix the student again to find partner be three members and the reseacher yells freeze to the student read the text 
and answer the next question. After finish the time given the teacher mix again for the thirth time for find partner be three members, Next student read again the text and discuss their opinions, or respond to a comment to answer the next question when the reseacher yells freeze, it will be continue until five group and the group must answer the all question given.

When time is over the researcher gives time and chance for the Student to share again of the reading text and make conclusion of the text (Kagan, 1994).

\section{Effective Small Group Teaching}

Effective small group teaching is much more challenge task than is often realized. it is much more difficult for students to discuss coherently, to question, and think the underlying themes are getting students to talk to each other as well as a tutor-and getting students to think. we than explore the skill required by students as well as a tutors if small group teaching to be effective an ending it with guidlines for preparing for small group teaching and some suggestions for evaluating your own small group teaching.

The major theme of research on small group teaching in the past fifty years has been the question when small group teaching should be used. a review of over a hundred studies which used examination results as the sole criterion (Dubin and Taveggia 1968) suggested that small group teaching is only as effective as other methods of teaching-and more costly. This finding may tell us, more about the examination than the teaching. These reviews by more recent writers ( Kulik 1979; Bligh 1980; Jaques 1984 ) shows that small group teaching is usually better than other methods at promoting intellectual skills including problem-solving and at changing attitudes, and about as effective as other methods at presenting information. and small group teaching is an efficient method of imparting information- its potensial team work and share in the interplay of ideas and views that develop a student capacity to think.

\section{The Goals Of Small Group Teaching}

Put simply the immediate goals of small group teaching are to get students to talk and think. The long - term goals are personal growth and competence. These goals may be expressed in the form : 
a. The depelopment of communication skills

Discussion also develops skill that are central to most professions; the ability to communicate with others (both propessional and 'lay'), and the sensitive and precise handling of the language of the subject. This language contains not only concepts, fact, and processes many physicist value quantitative measurements, pure mathematicians are concerned with rigior of proofs, and historians with the quality of various types of evidence. So one of the goals of small group teaching may be socialize student into the values and perspectives of your own subject, dicipline, or profession. It may be important, therefore, for the teacher to be their subject' when small group teaching. In other words to show, discuss, and encourage certain ways of thinking, of using evidence, and of structuring ideas and procedures.

b. The development of intellectual and professional competencies

Every subject probably has its own style of thinking but also features in common with other styles. Some types of thinking:

- Analysing

- Logical reasoning

- Appraising and judging perceptively

- Thinking critically

- Seeing new relationship

- Arguing rationality

- Transferring skill to new contexts

- Problem solving

However, it is not all professional competencies are concerned with thinking practical procedures may be at least as important. And small group teaching is only one way in which intellectual and professional competencies may be developed. However, small group teaching is, potentially, a powerful method of encouraging students to think generally and in the specific modes for the subject.

c. The personal growth of students (like tutor ) 
The goals of personal growth necessarily includes the development of communication skills and thinking. It also include the notions of developing your self confidence, managing your own learning, working with others, and insigh into your self and others. In the short term attention to the affective goals may well encourage the group to talk and think. In the long term attention to these goals may assist a person to develop professionality as well as personality.

These three goals are interconnected in practice and each has implications for the role of the students in small group teaching. For the goals to be achieved the teacher has to consider the students involved as well as the task. Indeed the teachers' role is three fold: managing the learning task, the individuals, and the group process. ( Brown and Atkins; 1987; 52, 54 ).

\section{Concept of Reading Comprehension}

Reading comprehension is complex process in which the readers uses mental content to obtain the meaning from written materials. It means that reading is a complex process in which the reader is supposed to recognized meaning of printed words; it can be that reading comprehension is capability to understand of paragraphs, the ideas of one passage. In other words, reading comprehension is the act of what the eyes have been in finding information from the reading passage both explicitly, implicitly, and ability to describe the conclusion from the information.

Smith and Robinson (2007:7) states reading comprehension is complex process in which the readers uses mental content to obtain the meaning from written materials. It means that reading is a complex process in which the reader is supposed to recognized meaning of printed words; it can be that reading comprehension is capability to understand of paragraphs, the ideas of one passage

\section{Levels of Reading Comprehension}

The levels of Reading Comprehension according to Smith (1977:107) are: Literal reading, Interpretative reading, Critical reading and Creative reading. But Reseacher will not explaine all of them in detailly, but only specific information, sequencing event, and creative reading which is corelated with the variables, it will be shown as below : 


\section{a. Literal Reading}

Literal reading refers to the acquisition of meaning of ideas or information that is explicitly stated in the text. Some specific reading skill at the literal level of comprehension are: identifying specific information, sequencing event when explicitly.

\section{1) Identifying Specific Information}

This reading requires one to focus his attention only on one or some particular information or detail which he need form a text; the rest of the text may not be read anymore. That information may be a name, a date, a scientific term, or a place or just anything, the search for which motivates the person to read. In looking for a detail, the reader must look for signals in the environment of the needed information or in the information it self.

2) Sequencing Events

Meaningful reading results from the reader's ability to follow the flow of thought of the writer. This is so because any discourse is made up of words and sentences which are not only grammatically linked to one another, but also related with conflict and plot, the basic conflict is dramatic conflict. For convinience, we can place the dramatic conflict that foubd in short stories in three categories. Those are:

a) First is the fhisical or Elemental Conflict. Here we usually find a person or thing in conflict with nature. In such a story we may go through the struggles of a man climbing a mountain, a woman fighting to survive in acycloue,etc. The principal appeal of kind of story is almost wholly to the emotions of the reader.

b) The second types of dramatic conflict is Social conflict. In this type the is of one person against another:two women seeking to marry the same man, two men competing for job, a detective pitted against a criminal, a child in conflict with his parents,etc. The principal the conflict happen between the actor to another actor.

c) The tird type of confict is Internal or Psychological conflict. Here we find a person struggling against with him or her self, his conscience, his guilt, 
or simply trying to decide what he's going to do. In such a story we may see an honest man but poor, a women struggling with the consequence of a lie she's told, or unwanted pregnant girl trying to decide whether to have an abortion, place her child up for adoption, or raise him alone, etc. The principal this conflict telling about anxious, doubt, uncertainly it self.

Sequence also related with plot, probably the most populer kind of story is the action of the story. In action story we concerned chiefly with what happen. Plot is planned by the author. The story moves from a beginning through a series of events to a climax or turning point, and to logical end. The inciting forces are those statements or happenings that excite the reader and are part of the build-up of the story. In a closed plot the author resolves or concludes the story for reader. In an open plot the story frequently ends at the climax, and the reader is left to decice what he thinks the resolution or outcome of the story might be ( Jones Jr. $1987: 30)$.

\section{b. Creative Reading}

Creative reading involves going beyond the material presented by the author, creative reading require the readers to think as they read just as critical reading and it also require the reader to use their imagination, in creative solution to those by the author. Creative reading, that is so apply ideas from the text to new situation and to combine author's ideas with other ideas to from new concepts or expand old ones. In creative reading the reader tries to purpose new alternative solution or response those by the writer. It requires readers feeling for the text and subject. The answers are not found in the text; they come strictly from the readers. While non personal responses are incorrect, they cannot be unfounded; they must relate to the content of the text and reflect a literal understand of the material.

According to Marshall (1998), creative reading is the readers'understood to involve the more predictable and manageable set of skills. The ability to accurately represent the argument in the assigned reading. While we do think the ability to accurately represent the ideas of other writer is of central importance. We also think that it is not just away to better comprehend the ideas of others, but can also be creative process for developing and then better understanding your 
own ideas as they relate to the ideas of others. Creative readers make sure that they know what the author is saying while, at the same time, devoting their energies to actively constructing otherwise implicit relationship between ideas, even, and context. Tha is, creative reading involves imagining how and why different position represented in the text migt be made to relate to each other.

Creative reading also means using your own experience and knowledge of the world to critically examine the ideas presented in the text. By considering an authors' ideas in new context, you can find your own ways to develope your own contribution to the public debate which these reading text (Mirriam \&Marshal 1998).

\section{RESEARCH METHODOLOGY}

\section{A. Research Design}

This is an action research (CAR) that conducted at SMA Negeri 1 Bonto Marannu. The subject of the research is the first grade students of the class X.8 in 2012-2013 academic years. In the observation the research used test to know the students prior knowledge in the class. In fact, the researcher has found the student's reading comprehension is very low.

\section{B. Research Instrument}

Basicly classroom action research has two main instruments which used collected data, they were observation sheet and reading test the function of each research. The observation sheet aims to measure the improvement and the effectiveness of students. Meanwhile, reading test is to find out the students result and response of teaching learning process through the use of Mix Freeze Group Strategy.

\section{The procedure of collecting data}

1. The data sources were got from:

a) Students gave data about their participation, responses and their comprehension in reading text through Mix freeze group Strategy

b) Teacher as the monitor of the implementation of mix freeze group teaching and students' participation, response and competence in reading text.

2. The data analysis which was received consisted of 
a) The result of the study as quantitative data

b) The result of observation as qualitative

The data from cycle 1 and cycle II had been analyzed the following steps:

1. To Score the students' answer of the test, the researcher used formula.

$$
\text { Students' Score }=\frac{\text { Total Score }}{\text { Maximum }} \times 100
$$

(Sudiyono, $2005:$ 43).

Scoring the students answer based on the following criteria, they were:

\section{Specific information dealing main ideas and sequences event}

\begin{tabular}{|l|c|}
\hline \multicolumn{1}{|c|}{ Indicators } & Score \\
\hline Student uses all relevant information stated directly in the text to answer the questions. & 40 \\
\hline Student uses most relevant information stated directly in the text to answer the questions. & 30 \\
\hline Student uses some relevant information stated directly in the text to answer the question. & 20 \\
\hline Student uses little or no relevant information stated directly in the text to answer the questions. & 10 \\
\hline
\end{tabular}

\begin{tabular}{|c|c|}
\hline reative reading dealing characterization and conclusion & \\
\hline $\begin{array}{l}\text { Student explain all the characters, telling the story what would like and make very good } \\
\text { conclusion }\end{array}$ & 40 \\
\hline $\begin{array}{l}\text { Student explains most of the characters, telling the story what would like and make good } \\
\text { conclusion }\end{array}$ & 30 \\
\hline Student explains some of the charaters, telling little of the story and make not good conclusion & 20 \\
\hline Student does not explain the charaters, telling just little the story but doesnt make conclusion & 10 \\
\hline
\end{tabular}

Maximum score $=40$

(Waltres : 1992)

2. Calculated the mean score of the students' reading test by using the following formula.

Where

$$
\overline{\mathbf{X}}=\frac{\sum \mathbf{X}}{\mathbf{N}}
$$

$$
\begin{array}{ll}
\overline{\mathbf{X}} & =\text { The Mean score } \\
\sum \mathrm{X} & =\text { The Total score } \\
\mathrm{N} & =\text { The Total number of Students }
\end{array}
$$

(Gay, 1981: 298)

\section{Classifying score of students reading comprehension}

\begin{tabular}{|c|l|c|}
\hline No & \multicolumn{1}{|c|}{ Classification } & Range \\
\hline 1 & Excellent & $96-100$ \\
\hline 2 & Very good & $86-95$ \\
\hline 3 & Good & $76-85$ \\
\hline 4 & Fairly Good & $66-75$ \\
\hline 5 & Fairly & $56-65$ \\
\hline 6 & Poor & $36-55$ \\
\hline 7 & Very Poor & $0.0-35$ \\
\hline
\end{tabular}


4. The data was taken from the observation, the researcher identify through the students' participation in teaching and learning process based on the criteria :

\section{The Students' Active Participation}

\begin{tabular}{|c|l|l|}
\hline No & \multicolumn{1}{|c|}{$\begin{array}{c}\text { The students' active } \\
\text { participation }\end{array}$} & \multicolumn{1}{c|}{ Indicator } \\
\hline 4 & Very Active & Students respond the material very actively \\
\hline 3 & Active & Students respond to the material actively \\
\hline 2 & Fairly Active & Students respond the material just one or twice \\
\hline 1 & Not Active & $\begin{array}{l}\text { Students just sit down during the activity without doing } \\
\text { something. }\end{array}$ \\
\hline
\end{tabular}

Students' participation were counted through percentage formula.

\section{FINDING AND DISCUSSION}

\section{The Improvement of the Students' Specific Information of The Text.}

The improvement of the students' reading comprehension of the text, which focused on Specific Information which is consist of main ideas, and sequence details as indicators in X8 SMAN 1 BONTO MARANNU as result of the students' assessment of Cycle I and Cycle II can be seen clearly in the following table:

Table 1. The Improvement of the Students' Specific information of the text

\begin{tabular}{|c|c|c|}
\hline Indicators & Cycle 1 & Cycle 2 \\
\hline Main Ideas & 57.06 & 68.68 \\
\hline Sequnces Details & 58.46 & 68.82 \\
\hline Total Score & 115.52 & 139.87 \\
\hline Mean Score & $\mathbf{5 7 . 7 6}$ & $\mathbf{6 9 . 9 3}$ \\
\hline
\end{tabular}

The table above indicates of the mean score specific Information in cycle 1 it indicates (57.76). and for cycle II it indicates (69.93). it is prooved that there is significant improvement from cycle 1 and to cyle II

To see clearly the improvement of the students' specific information of the text, the following chart is presented: 


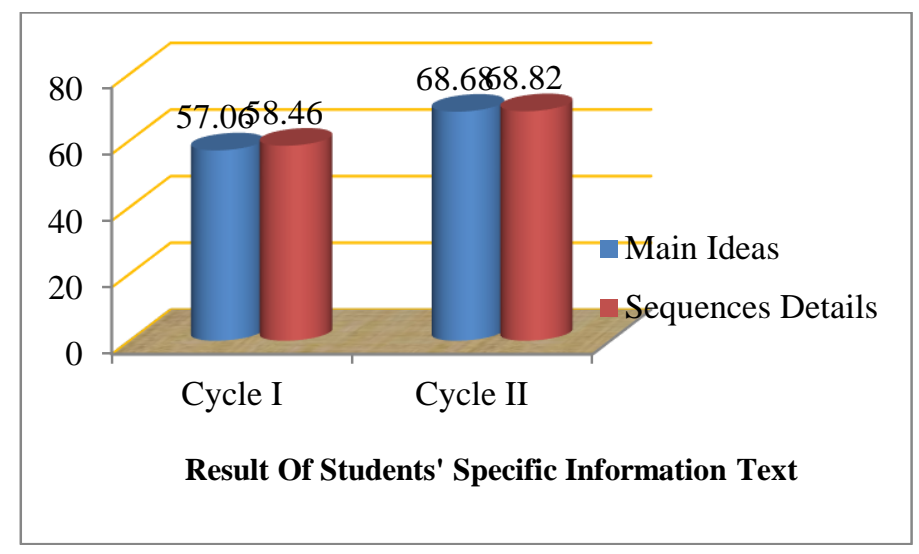

Figure 1: The Improvement of the Students' Specific Information of the text

The chard above shows that there is improvement of main ideas and

sequnces details from cycle 1 to cycle II. Where if we calculated the improvement of main ideas from cycle 1 is $20 \%$. and the improvement of sequences from cycle 1 to cycle II is $17.7 \%$

\section{The Improvement of the Students' Creative reading of the Text.}

The improvement of the students' reading comprehension of the text, which focused on Creative Reading which is consist of characterization and conclusion as indicators in X8 SMAN 1 BONTO MARANNU as result of the students' assessment of Cycle I and Cycle II can be seen clearly in the following table :

Table 2. The Improvement of the Students' Creative Reading of the text

\begin{tabular}{|c|c|c|}
\hline Indicators & Cycle 1 & Cycle 2 \\
\hline Characterization & 61.50 & 74.04 \\
\hline Conclusion & 65.71 & 81.91 \\
\hline Total Score & 127.21 & 155.95 \\
\hline Mean Score & $\mathbf{6 3 . 6}$ & $\mathbf{7 7 . 9 7}$ \\
\hline
\end{tabular}

The table above indicates of the mean score of creative reading in cycle 1 it indicates (63.6). and for cycle 2 it indicates (77.97). it is proove that there is significant improvement from diagnostic test without using method to cycle 1 and to cyle II which is used method..

To see clearly the percentage score improvement of the students' creative reading of the text following chart is presented 


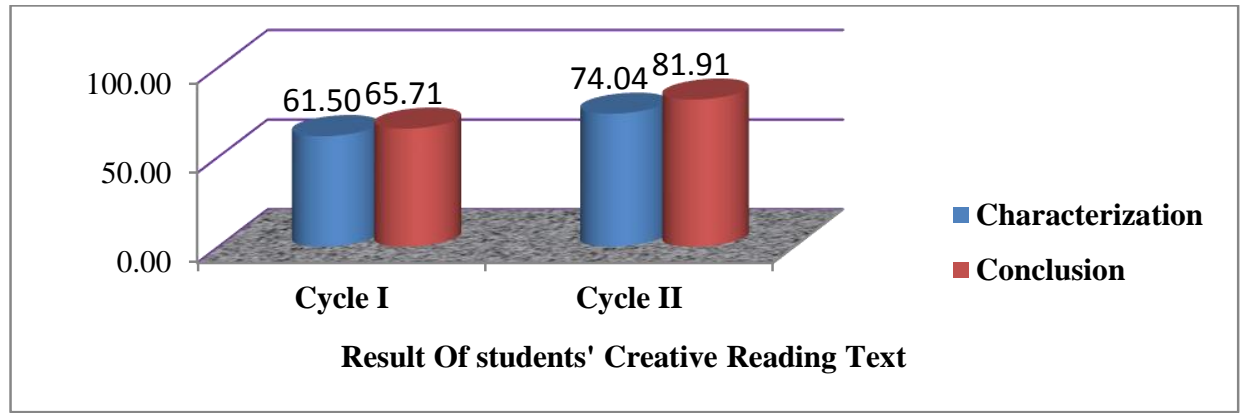

Figure 2: The Improvement of the Students' Creative Reading of the text

The chard above shows that there is improvement of characterization and coclusion from cycle 1 to cycle II. Where if we calculated the improvement of characterization from cycle 1 to cycle II is $20 \%$. and the improvement of coclusion from cycle 1 to cycle II is $33 \%$

3. The Improvement of the Students' Reading Comprehension of The Text. The improvement of the students' reading comprehension of the text, which focused on Specific Information and Creative Reading as indicators in X8 SMAN 1 BONTO MARANNU as result of the students' assessment of Diagnostic- Test, Cycle I and Cycle II can be seen clearly in the following table:

Table 3. The Improvement of the Students' Reading Comprehension of The Text

\begin{tabular}{|c|c|c|c|}
\hline Variables & $\begin{array}{c}\text { Diagnostic } \\
\text { Test }\end{array}$ & Cycle 1 & Cycle 2 \\
\hline Specific Information & 48.14 & 57.76 & 68.75 \\
\hline Creative Reading & 53.24 & 63.6 & 77.97 \\
\hline Total Score & 101.38 & 121.36 & 146.72 \\
\hline Mean Score & $\mathbf{5 0 . 7}$ & $\mathbf{6 0 . 7}$ & $\mathbf{7 3 . 3 6}$ \\
\hline
\end{tabular}

The table above indicates of the mean score of reading comprehension in diagnostic test is (50.7), for cycle 1 it indicates (60.7). and for cycle II it indicates (73.36). it is proove that there is significant improvement from diagnostic test without using method to cycle 1 and to cyle II by using method.. 
To see clearly the improvement of the students' reading comprehension, following chart is presented:

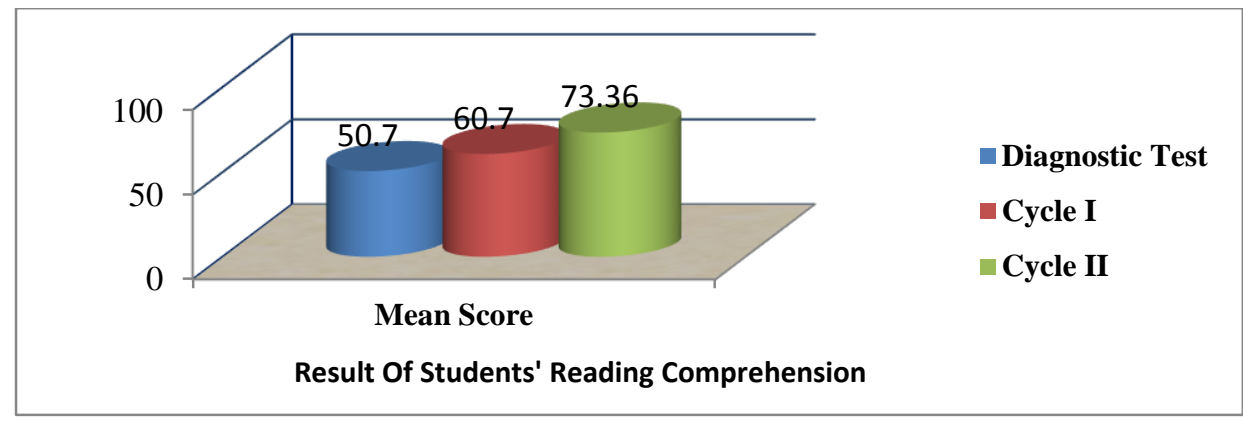

Figure 3: The Improvement of the Students' Reading Comprehension

The chart above shows very clearly that there is improvement of the students' reading comprehension from diacnostic test to cycle I and cycle 1 to cycle II where when we calculated the improvement from diacnostic test to cycle 1 is $19 \%$ and improvement from cycle 1 to cycle II is $20 \%$ and the improvement from diagnostic test to cycle II is $44 \%$

\section{The Result of the Students' Activeness in Learning Process.}

The result of observation of the students' activeness in teaching and learning process during 8 meetings was taken by the observer through observation sheet. It could be seen clearly through the following table:

\section{Table 4. The Result of the Students' Activeness in Each Meeting}

\begin{tabular}{|c|c|c|c|c|c|c|}
\hline \multirow[b]{2}{*}{ Cycle } & \multicolumn{4}{|c|}{ Meetings } & \multirow{2}{*}{$\begin{array}{c}\text { Average } \\
\text { Score }\end{array}$} & \multirow[b]{2}{*}{ Improvement } \\
\hline & I & II & III & IV & & \\
\hline I & $68.57 \%$ & $62.14 \%$ & $70 \%$ & $79.28 \%$ & $69.99 \%$ & \\
\hline II & $73.57 \%$ & $80 \%$ & $77.85 \%$ & $81.42 \%$ & $78.21 \%$ & $11.74 \%$ \\
\hline
\end{tabular}

The table above explains about the average of the students' activeness in teaching and learning process through observation sheet by observer. The table above shows the process the students' activity in each meeting. The percentages of the cycle I from the first meeting to the fourth meeting are $68.57 \%, 62.14 \%$, $70 \%$ and $79.28 \%$. Moreover, the percentage of the cycle II from the first meeting to the fourth meeting are $73.57 \%, 80 \%, 77.85 \%$ and 81.42 . 
To see clearly the improvement of the students' activeness, following chart is presented:

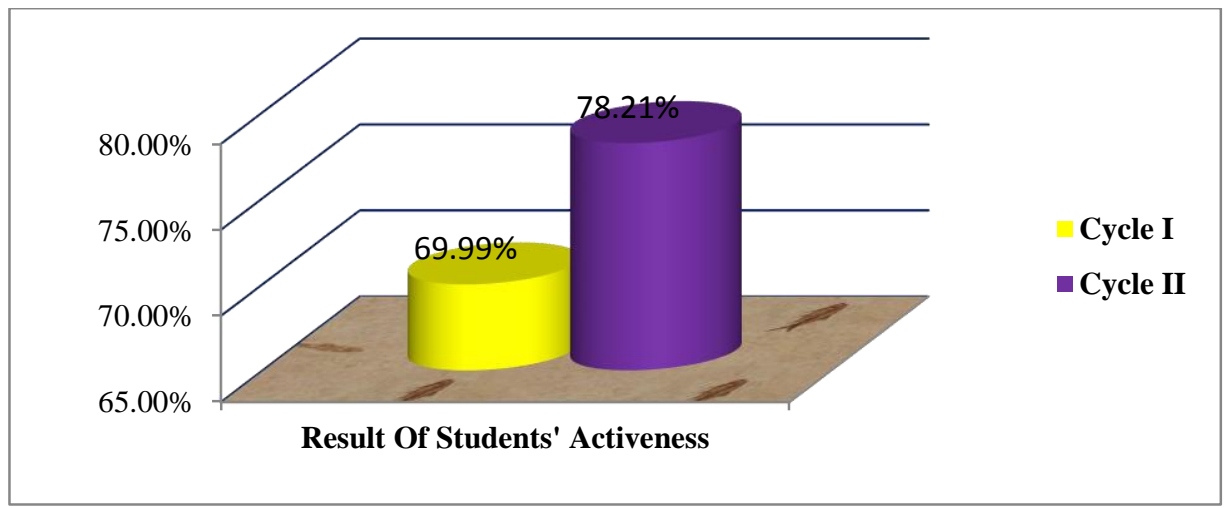

Figure 7: The students' observation in learning reading skills.

The chart above, presented the students' situation during teaching and learning process in reading from cycle I to the cycle II. From the graphic it is known that there is a changing of students' situation in learning reading is $69.99 \%$ and the changed to be $78.21 \%$ with improvement $11.7 \%$

\section{B. Discussions}

In this part, discussion deals with the interpretation of findings derived from the result of findings about the students' specific information of the text consist of main ideas and sequence details and creative reading of the text consist of characterization and conclusion. The application of Mix Freeze Group Strategy in teaching reading comprehension at the X8 of SMAN 1 Bonto Marannu can improve the students' achievement and their ability to understand the material of reading comprehension in cycle I and cycle II inside the learning process and KKM in SMAN 1 Bonto Marannu specially English subject is $\mathbf{6 5}$.

Before taking a classroom action research through Mix Freeze Group Teaching Strategy, the researcher hold diagnostic test to measure the students' prior knowledge in English reading. After gave diagnostic test, the researcher found that the students' reading comprehension at the first grade, X8 of SMAN 1 Bonto Marannu was very poor, so it must be improved. The diagnostic tests score was that all of students' got very poor, it was $\mathbf{5 0 . 7}$

To improve the students' reading comprehension, the researcher decided to use Mix Freeze Group Strategy and then prepared to do cycle I that consisted of 4 
phases namely: planning, action, observation, and reflecting. In cycle I, the researcher found that the students still difficult and confused to comprehend the text, expecially for specific information mainly sequnce detail. The students still was difficult to found the conflict of the story and the plot of the story. Eventhough the resecearcher had been explained of that, not only that, the students also still was difficult to mention and explaine the kind of the character in the story, they only mentioned good or bad but didn't explained why they thought it for eventhought the students read and share with their group to answer the question. The difficulty of the students in reading had been analyzed, so the researcher had to think the solution of the problem. The researcher decided to do cycle II by doing revision in the lesson plan. In cycle II, the researcher gave more explanation again of the sequnce detail and characterization, the researcher got a good response from the students, most of them asked question to the researcher about the explanation, and they really entustiastic to read again to share again of the text by the method. Students are fair active in classroom. They can enjoy the teaching and learning process, and their score was improved in cycle II.

The researcher find The main score of main ideas in diagnostic test is 47.57. and for sequence details in diagnostic test is 48.71. it is the result of specific information of the text in diagnostic test before using the method. And the students reading comprehension in diacnostic test is 50.7. it is under the KKM of the school, so the researcher doing action in cycle 1 to improve the students reading comprehension, and the researcher got result of main ideas in cycle 1 is 57.06, sequnce details is 58.46. For Creative reading which is dealing with characterization and conclusion, the researcher find score of characterization in diagnostic test is 52.91. and 61.50 in cycle I. And the result of conclusion in diagnostic test is 53.57, and in cyle 1 is 65.71 . and the students reading comprehension with score 60.7 in cycle 1 . it is indicates that there is improvement of students reading comprehension from diagnostic test to cycle 1 but it is still under KKM. So the researcher continue doing cycle II.

The researcher find the main score of main ideas in cycle II is 68.68. and for sequence details in cycle II is 68.82 . it is the result of specific information of the 
text in cycle II by using the method. And For Creative reading which is dealing with characterization and conclusion, the researcher find score of characterization in cyle II is 74.04 and the result of conclusion in cycle II is 81.91 . and the students reading comprehension with score 73.36 in cycle II. it is indicates that there is improvement of students reading comprehension from cycle 1 to cycle II and is reach the KKM.

The significant improvement of the students' specific information of the text from diacnostic test to cycle I to cycle II where the students' specific information of the text in diacnostic test is 48.14 , in cycle $\mathrm{I}$ is 57.76 and in cycle II is 68.75 . Thus, the improvement of students' specific information of the text achievement from diacnostict test to cycle II is $0.44 \%$, where the improvement of main ideas from diacnostic test to cycle II .is 0.44 and improvement sequence details from diacnostic test to cycle II is 0.41 .

Finally, the mean score of reading comprehension through Mix freeze Group Teaching Strategy in cycle II 73.36 and 60.7 in cycle I and 50.7 in diacnostic test. With the students' improvement from diagnostic tes to Cycle II is $20.90 \%$. It means that the students' reading comprehension improved significantly and reached the target score is $\mathbf{7 0}$ through Mix Freeze Group Teaching Strategy.

The students' activeness in each meeting. The percentages of the cycle I from the first meeting to the fourth meeting are $68.57 \%, 62.14 \%, 70 \%$ and 79.28\%. Moreover, the percentage of the cycle II from the first meeting to the fourth meeting are $73.57 \%, 80 \%, 77.85 \%$ and $81.42 \%$. In addition, the average score in every cycle, in cycle I is $69.99 \%$ and in cycle II is $78.21 \%$. Hence, the improvement of the students' activeness is $11.74 \%$.

Based on the discussion above, we can know that there wis different result between diagnostic test to cycle I and cycle II in teaching reading through Mix Freeze Group Teaching Strategy. The researcher may say that teaching reading through Mix Freeze Group Teaching Strategy is a good way to improving the students' reading comprehension. 


\section{CONCLUSION AND SUGGESTION}

\section{A. Conclusion.}

The use of Mix Freeze group Teaching Strategy in presenting the reading comprehension material at the X8 class students' of SMA Negeri 1 Bonto Marannu improves the students' achievement significantly. The findings indicate that the mean score of test for cycle II is greater than the mean score of test for cycle I. In addition, Mix Freeze Group Teaching Strategy can improve the students' reading comprehension in terms of finding the Specific information of the text dealing in main ideas and sequence events at the students' of X8 class SMA Negeri 1 Bonto Marannu. Moreover, it can improve the students' reading comprehension in terms of finding the Creative reading of the text dealing in Characterization and conclusion at the students' of X8 class SMA Negeri 1 Bonto Marannu.

\section{B. Suggestion.}

Based on the conclusion above, the researcher addresses suggestion to the teachers should use Mix Freeze Group Teaching Strategy as the alternative among to be used in teaching reading comprehension. It is suggested that the English teachers should use Mix Freeze group Teaching Strategy in presenting the reading comprehension materials, because it is effective to improve the students' achievements. For the teachers, they attempt to call up all the abilities to increase the learning process quality as responsibility by doing or using a Classroom Action Research in many classes. Furthermore, for next researcher, they use Mix Freeze group Teaching Strategy in doing researchers, because it can give enough opportunity to the students to practice their reading comprehension.

\section{REFERENCES}

Barbara\&Kathy1998.kathy@auecc.aichi-edu.ac.jp.and www.KaganOnline.com

Brown, George and Atkins, Madeline; 1987. Effective Teaching In Higher education

Canfield,J.\&Wells,H.C.1997. 100 Ways to Enhance Self confidence 
Dark and Silberstain. 2011 http://www.lextutor.ca/cv/webthesis/Thesis8.html. Accessed on July 20, 2011

Dubin and Taveggia 1968; Argyle 1983. Effective small group method

Edward H. Jones Jr; 1987. Short stories, Elcamino Collage

Goldschmid,.http://www.educatiosn.com/reference/article/constructivism/.

Accessed on July 12, 2011

JALT, Japan Association for Language Teaching,(Kluge et al,1999;Poel 1994)

Kagan, Spencer 1994. http://www.kaganonline.com/KaganClub/FreeArticles/ ASK17.html

Kulik 1979; Jaques 1984 and Bligh 1980, Small group method

Laura Candler $\sim$ Teaching Resources $\sim$ www.lauracandler.com

McCarty. http://iteslj.org/Articles/McCarthy-Reading.html. Accessed on August 02,2011

Mirriam \& Marshal. http://www.Mirriam-reading.html. Accessed on october 1998

Nuttal, 2000. The purpose enhance knowledgeof language being read. New York Cambrige University

Richard, J. Miller S.T. 1986. Approach and method in Language Teaching. A Creative Reading and Analysis. New York: Cambridge university Press.

Smith and Robinson. 2007. Reading in a Foreign Language. London, Longman pp 181-198.

Smith, N.B 1977. Reading Instruction for Today's Children. Boston; PracticeHall, inc.

Kagan,Spencer . 1994. Cooperative Learning 27134 Paseo Espada

Thinker and Mc Collough, Reading Ability the first edition ( 1975;9)

Walters;1992. How to write a good conclusion essay. Vol.1 Retrieved from http:// Collage livetext.com.doc.on November 242011. 